\title{
Pattern of hospitalized-stroke patients in ASEAN countries an ASNA stroke epidemiological study
}

\author{
Jusuf Misbach
}

\begin{abstract}
Abstrak
Untuk lebih memahami gambaran karakteristik, waktu tiba, pola klinis, faktor risiko, jenis stroke, lama rawat, dan status keluaran dari pasien stroke akut di negara-negara ASEAN maka ASNA ( Perhimpunan Neurologi ASEAN) membentuk komisi khusus Stroke pada tahun 1996 dan laporan ini merupakan hasil Penelitian Epidemiologi Stroke ASNA yang pertama dengan protokol yang sama Penelitian studi berbasis hospital secara prospektif di tujuh negara ASEAN yaitu Brunei ( $n=53$ ), Indonesia ( $n=2065$ ), Malaysia $(n=300)$, Filipina $(n=545)$, Singapura $(n=232)$, Thailand $(n=244)$, dan Vietnam $(n=284)$ dengan melibatkan para spesialis neurologi selama periode Oktober 1996 sampai Maret 1997. Dari 3723 penderita stroke yang diteliti (55\% pria dan 45\% wanita), usia rerata adalah 59,0 $\pm 13,8$ tahun, 16\% pasien lebih muda dari 45 tahun dan 37\% pasien lebih tua dari 65 tahun. Tidak ada perbedaan bermakna dari usia onset penderita stroke tersebut kecuali di Vietnam (lebih muda) dan Singapura (lebih tua). Distribusi jenis kelamin memperlihatkan prevalensi yang sedikit lebih tinggi pada wanita di Singapura dan pada usia $>64$ tahun. Waktu tiba rerata adalah 41,5 $\pm 87,0$ jam, $19 \%$ pasien masuk dalam 3 jam, dan 66\% lebih dari 6 jam (terlambat) terutama di Malaysia dan Singapura $(80 \%$ dan $77 \%)$. Gangguan motorik merupakan gejala klinis yang paling menonjol pada semua negara dan bising karotis paling sedikit dijumpai (1 \%). Hipertensi adalah faktor risiko tertinggi pada semua negara (68\%), diikuti TIA (35\%), merokok, diabetes melitus, penyakit koroner dan hiperkolesterolemia. Sken tomografik dilakukan pada $76 \%$ pasien. Klasifikasi diagnostik terdiri dari non lakuner anterior (32\%), lakuner (14\%), hemoragik (26\%). Lama rawat rerata 11,4 $\pm 11,8$ hari. Sebagian besar membaik pada saat keluar rumah sakit dan kematian terjadi pada $22 \%$ penderita, tertinggi di Thailand (45\%) dan terendah di Brunei (8\%). Data stroke yang diteliti menunjukkan pola stroke yang terbaru di tujuh negara ASEAN dan data ini sangat penting bagi pembuat kebijakan di negara-negara ini dan untuk dasar penelitian bersama di masa mendatang. (Med J Indones 2001; 10: 48-56)
\end{abstract}

\begin{abstract}
To better understanding the demographic characteristics, admission time, clinical pattern, risk factors, stroke type, length of stay, and discharge outcome of hospitalized acute stroke patients in ASEAN member countries, ASEAN Neurological Association (ASNA) formed a Standing Committee for Stroke in 1996 and this is the first ASNA Stroke Epidemiological Study using the same stroke protocol. This prospective hospital based study was conducted in seven ASEAN countries (Brunei, Indonesia, Malaysia, Philippines, Singapore, Thailand, and Vietnam) by participating neurologists from October 1996 to March 1997. Of the 3723 consecutive hospitalized stroke patients (2030 males and 1660 females) from 44 participating hospitals in this study ie Brunei ( $n=53$ ), Indonesia $(n=2065)$, Malaysia $(n=300)$, Philippines $(n=545)$, Singapore $(n=232)$, Thailand $(n=244)$ and Vietnam $(n=284)$, the mean age was 59.0 $\pm 13,8$ years $16 \%$ of patients were younger than 45 years and $37 \%$ of patients were older than 65 years. There were no significant differences in age at onset among stroke subjects except in Vietnam (younger) and Singapore (older).The sex distribution showed a slight higher prevalence of women in Singapore and in the age group $>64$ years. The mean admission time was $41.5 \pm 87.0$ hours, $19 \%$ of patients were admitted within 3 hours, $29 \%$ within 6 hours and $66 \%$ more than 6 hours (delayed admission) especially in Malaysia and Singapore $(80 \%$ and $77 \%$ respectively). Motor disability was the most prevalent clinical feature in all countries and carotid bruit was the rarest (1\%). Hypertension was the most common risk factor (68\%) in all countries, followed by TIA (35\%), smoking, diabetes mellitus, ischaemic heart disease and hypercholesterolemia. CT scan was performed on $76 \%$ of subjects. The diagnostic classification was non lacunar anterior circulation (32\%), lacunar infarction (14\%), hemorrhagic stroke (26\%), SAH (4\%). Mean length of stay was $11.4 \pm 11.8$ days. Most of the patients discharged from the hospital were alive improved $(57 \%)$ and mean death rate was $22 \%$, highest in Thailand (45\%) and lowest in Brunei (8\%). This hospital based stroke data showed the recent characteristics of stroke pattern in seven ASEAN member countries and it will be very important data for health policy maker in these countries and for further cooperative researches in the future. (Med J Indones 2001; 10: 48-56)
\end{abstract}

Key Words: Stroke, clinical pattern, risk factor.

On behalf of ASNA Standing Committee For Stroke Department of Neurology

Faculty of Medicine, University of Indonesia, Jakarta, Indonesia 
Seven members of neurological association in ASEAN Countries consist of Brunei, Malaysia, Indonesia, Philippines, Singapore, Thailand and Vietnam had founded ASEAN Neurological Association (ASNA) in 1995. One of the programs of the organization was to conduct cooperative epidemiological studies in seven ASEAN Countries. A Standing Committee For Stroke was formed in Jakarta in July 1996 and the first project was to conduct a stroke epidemiological study in ASEAN member countries. The aim of this hospital based study was to investigate the demographic characteristics, stroke types, clinical features, risk factors, and discharge status of the hospitalized stroke patients admitted from October 1996 to March 1997, using the uniform protocol. This is the first cooperative study done in the region.

\section{METHODS}

A stroke protocol were designed and distributed to all participating hospitals by representative neurologists of each countries. Over six month period from October 1996 to March 1997, all consecutive acute stroke patients admitted to the participating hospitals were included in the study.

Stroke is defined as "rapidly developing signs of focal disturbances of cerebral functions, leading to death or disability, lasting longer than 24 hours, with no apparent cause other than vascular" (WHO,1989).

Demographic data, clinical features, risk factors, brain CT scan data, classification of stroke and hospital discharge status were collected prospectively. These data were stored in a prepared floppy diskette. Analysis were made using SPSS for Window 9.0 packages.

\section{RESULTS}

\section{Demographic characteristics}

Totally, 3723 stroke patients from 44 hospitals were participated in this study, consisted of 53 patients from Brunei (one hospital), 300 patients from Malaysia (two hospitals), 2065 patients from Indonesia (28 hospitals), 545 patients from Philippines (eight hospitals), 232 patients from Singapore (two hospitals), 244 patients from Thailand (two hospital), 284 patients from Vietnam (one hospital), the patients consisted of 2030 males, 1660 females and $33(1 \%)$ sexes were not reported. The age of patients ranged from 4 to 95 years $(59.0 \pm 13.8$ years old). As many as 579 patients ( $16 \%$; 340 males and 239 females) were younger than 45 years, whereas 1355 patients (37\%, 655 males and 700 females) were older than 64 years. No significant differences in the onset of stroke was noted, except that patients in Vietnam who were younger and patients in Singapore who were older than those from other countries. The sex distribution of stroke patients showed a slight higher prevalence of women in Singapore and in the age group more than 64 years. The distribution of age and sex of the patients in these countries was shown in Table 1.

Table 1. Distribution of stroke subjects in the participating country

\begin{tabular}{lcc}
\hline Country & no. of patient & $\begin{array}{c}\text { no. of } \\
\text { hospital }\end{array}$ \\
\hline Brunei & 53 & 1 \\
Malaysia & 300 & 2 \\
Indonesia & 2065 & 28 \\
Philippines & 545 & 8 \\
Singapore & 232 & 2 \\
Thailand & 244 & 2 \\
Vietnam & 284 & 1 \\
\hline \multicolumn{1}{c}{ total } & 3723 & 44 \\
\hline
\end{tabular}

\section{Admission time}

Of 3723 patients in this study, 165 patients (4.4\%) were excluded from the admission time analysis because of lack of information about the hour of onset of symptoms. The mean time between onset of symptoms and hospital arrival was 41.5 hours (SD 87.0 hours; range, 1-968 hours). Cumulatively, 701 (19\%) patients were admitted within 3 hours, 1087 (29\%) within 6 hours and $2471(66 \%)$ patients more than 6 hours. A comparison of participating countries based on admission time is shown in Table 2. The prevalence of stroke patients with delay admission (more than 6 hours after the onset) in Malaysia and Singapore were higher than those from other countries ( $80 \%$ and $77 \%$, respectively). 
Table 2. Age and Sex Distribution of Hospitalized Stroke Patients in ASEAN Countries.

\begin{tabular}{llllllllll}
\hline $\begin{array}{c}\text { Age range, } \\
\text { year }\end{array}$ & Sex & $\begin{array}{l}\text { Brunei } \\
\mathrm{n}=53\end{array}$ & $\begin{array}{l}\text { Indonesia } \\
\mathrm{n}=2036\end{array}$ & $\begin{array}{l}\text { Malaysia } \\
\mathrm{n}=300\end{array}$ & $\begin{array}{l}\text { Philippines } \\
\mathrm{n}=545\end{array}$ & $\begin{array}{l}\text { Singapore } \\
\mathrm{n}=232\end{array}$ & $\begin{array}{l}\text { Thailand } \\
\mathrm{n}=242\end{array}$ & $\begin{array}{l}\text { Vietnam } \\
\mathrm{n}=282\end{array}$ & $\begin{array}{l}\text { Total } \\
\mathrm{n}=3690\end{array}$ \\
\hline$<45$ & male & 5 & 153 & 20 & 57 & 7 & 30 & 68 & 340 \\
& female & 2 & 112 & 18 & 30 & 3 & 20 & 54 & 239 \\
& total & $7(13)$ & $265(13)$ & $38(13)$ & $87(16)$ & $10(4)$ & $50(20)$ & $122(43)$ & $579(16)$ \\
$45-64$ & male & 15 & 601 & 84 & 147 & 54 & 63 & 71 & 1035 \\
& female & 9 & 435 & 44 & 102 & 47 & 47 & 37 & 721 \\
& total & $24(45)$ & $1036(51)$ & $128(42)$ & $249(46)$ & $101(44)$ & $110(46)$ & $108(38)$ & $1756(47)$ \\
$>64$ & male & 11 & 344 & 72 & 96 & 48 & 49 & 35 & 655 \\
& female & 11 & 391 & 62 & 113 & 73 & 33 & 17 & 700 \\
& total & $22(42)$ & $735(36)$ & $134(45)$ & $209(38)$ & $121(52)$ & $82(34)$ & $52(19)$ & $1355(37)$ \\
\hline total & male & $31(59)$ & $1098(54)$ & $176(59)$ & $300(55)$ & $109(47)$ & $142(59)$ & $174(62)$ & $2030(55)$ \\
& female & $22(41)$ & $938(46)$ & $124(41)$ & $245(45)$ & $123(53)$ & $100(41)$ & $108(38)$ & $1660(45)$ \\
\hline
\end{tabular}

values are number ( percentage )

\section{Clinical features}

Clinical characteristics of hospitalized stroke patients in different ASEAN countries are listed in Table 4. Motor disability ( $89 \%$ ) was the most frequent clinical feature seen in seven ASEAN countries, followed by headache ( $40 \%$ ), dysarthria (32\%), sensory disability $(29 \%)$, vomiting $(23 \%)$, dysphasia $(20 \%)$, drowsiness $(20 \%)$, coma (16\%) and vertigo (12\%). Seizure was found in $294(8 \%)$ of the patients, most frequent in Vietnamese $(12 \%)$ and rarest in Singaporean and Malaysian (2\% and 3\%, respectively). Carotid bruit was only found in $51(1 \%)$ patients.
The characteristics and prevalence of the stroke risk factors in different ASEAN countries are listed in Table 4. Hypertension was the most frequent risk factor $(68 \%)$ found in stroke patients in ASEAN countries consisted of hypertension treated $(35 \%)$, untreated $(26 \%)$ and diagnosed after admission (7\%). Hypertension were the commonest risk factor, particularly in patients with stroke in Indonesia (75\%), Philippines (72\%) and Singapore (69\%).

Approximately one fifth of patients had recurrent stroke in each country except in Vietnam and Malaysia (only $7 \%$ and $9 \%$, respectively). Diabetes mellitus, ischemic heart disease and atrial fibrillation

Table 3. Admission Time of Hospitalized Stroke Patients in ASEAN Countries

\begin{tabular}{lllllllll}
\hline $\begin{array}{l}\text { admission time } \\
\text { range, hour }\end{array}$ & $\begin{array}{l}\text { Brunei } \\
\mathrm{n}=52\end{array}$ & $\begin{array}{l}\text { Indonesia } \\
\mathrm{n}=1979\end{array}$ & $\begin{array}{l}\text { Malaysia } \\
\mathrm{n}=300\end{array}$ & $\begin{array}{l}\text { Philippines } \\
\mathrm{n}=481\end{array}$ & $\begin{array}{l}\text { Singapore } \\
\mathrm{n}=232\end{array}$ & $\begin{array}{l}\text { Thailand } \\
\mathrm{n}=242\end{array}$ & $\begin{array}{l}\text { Vietnam } \\
\mathrm{n}=272\end{array}$ & $\begin{array}{l}\text { Total } \\
\mathrm{n}=3558\end{array}$ \\
\hline mean, & 51.0 & 50.4 & 26.4 & 39.4 & 36.8 & 26.2 & 12.1 & 41.5 \\
sd & 110.4 & 100.3 & 35.6 & 84.8 & 72.2 & 55.6 & 18.7 & 87.0 \\
range & $1-720$ & $1-968$ & $1-240$ & $1-720$ & $1-720$ & $1-432$ & $1-150$ & $1-968$ \\
$<3$ hours & $9(17)$ & $356(17)$ & $29(10)$ & $122(22)$ & $44(20)$ & $89(37)$ & $52(18)$ & $701(19)$ \\
3-6 hours & $6(11)$ & $211(10)$ & $29(10)$ & $64(12)$ & $6(3)$ & $28(11)$ & $42(15)$ & $386(10)$ \\
$>6$ hours & $37(70)$ & $1412(69)$ & $242(80)$ & $295(54)$ & $182(77)$ & $125(52)$ & $178(63)$ & $2471(66)$ \\
\hline
\end{tabular}

values are number ( percentage) 
Table 4. Clinical Characteristics of Hospitalized Stroke patients in ASEAN Countries

\begin{tabular}{lllllllll}
\hline Characteristics & Brunei & Indonesia & Malaysia & Philippines & Singapore & Thailand & Vietnam & Total \\
\hline male/female & $31 / 22$ & $1108 / 944$ & $176 / 124$ & $300 / 245$ & $109 / 123$ & $142 / 100$ & $171 / 113$ & $2057 / 1666$ \\
& $(58 / 42)$ & $(54 / 46)$ & $(59 / 41)$ & $(55 / 45)$ & $(47 / 53)$ & $(59 / 41)$ & $(60 / 40)$ & $(55 / 45)$ \\
age, year & & & & & & & & \\
-range & $24-90$ & $8-95$ & $11-91$ & $12-95$ & $24-93$ & $15-93$ & $4-93$ & $4-95$ \\
-mean & 61.1 & 59.3 & 61.4 & 59.3 & 65.6 & 58.1 & 48.2 & 59.0 \\
-sd & 13.7 & 12.3 & 14.1 & 13.9 & 12.0 & 15.8 & 17.2 & 13.8 \\
motor disability & $48(91)$ & $1852(90)$ & $282(94)$ & $481(88)$ & $183(79)$ & $206(85)$ & $244(86)$ & $3296(89)$ \\
sensory disability & $12(23)$ & $557(27)$ & $45(15)$ & $274(50)$ & $50(22)$ & $27(11)$ & $130(46)$ & $1095(29)$ \\
Visual disorder & & & & & & & & \\
(hemianopia) & $5(9)$ & $71(4)$ & $1(0.3)$ & $97(18)$ & $18(8)$ & $6(3)$ & $49(17)$ & $247(7)$ \\
Dysarthria & $13(25)$ & $724(35)$ & $102(34)$ & $211(39)$ & $60(26)$ & $44(18)$ & $19(7)$ & $1173(32)$ \\
Dysphasia & $19(36)$ & $321(16)$ & $134(45)$ & $137(25)$ & $29(13)$ & $20(8)$ & $85(30)$ & $745(20)$ \\
Headache & $13(25)$ & $819(40)$ & $84(28)$ & $228(42)$ & $18(8)$ & $79(33)$ & $257(91)$ & $1498(40)$ \\
Vomiting & $8(15)$ & $459(22)$ & $36(12)$ & $153(28)$ & $28(12)$ & $65(27)$ & $123(43)$ & $872(23)$ \\
Vertigo & $6(11)$ & $184(9)$ & $28(9)$ & $122(22)$ & $30(13)$ & $15(6)$ & $47(17)$ & $432(12)$ \\
Unconscious & & & & & & & & 5 \\
- coma & $5(9)$ & $377(18)$ & $27(9)$ & $50(9)$ & $18(8)$ & $69(29)$ & $48(17)$ & $594(16)$ \\
- drowsy & $9(17)$ & $367(18)$ & $81(27)$ & $131(24)$ & $36(16)$ & $91(38)$ & $43(15)$ & $758(20)$ \\
Seizure & $6(11)$ & $180(9)$ & $9(3)$ & $35(6)$ & $5(2)$ & $26(11)$ & $33(12)$ & $294(8)$ \\
Dysequilibrium & $6(11)$ & $78(4)$ & $11(4)$ & $51(9)$ & $47(20)$ & $14(6)$ & $16(6)$ & $223(6)$ \\
Carotid bruit & $2(4)$ & $7(0.3)$ & $25(8)$ & $4(0.7)$ & $3(1)$ & $1(0.4)$ & $9(3)$ & $51(1)$ \\
Carotid stenosis $>60 \%$ & - & $14(0.7)$ & $4(1)$ & $12(2)$ & $8(3)$ & - & - & $38(1)$ \\
Cruit + stenosis & - & - & $1(0.3)$ & - & $1(0.4)$ & - & - & $2(0.1)$ \\
\hline & & & & & & & & \\
& & & & & & & & \\
\end{tabular}

values are number ( percentage )

were frequently found in ASEAN stroke patients except in Vietnam. On the other hand, prior TIA was the second most frequent risk factor (35\%) found in Vietnam. The habits of smoking and alcohol drinking were found more often among the stroke patients in Philippines and Malaysia rather than those from other countries. The less frequent risk factors in all countries were congestive heart disease $(4 \%)$, valvular heart disease (3.8\%) and contraceptive pills (1.2\%). Serum levels of cholesterol as well as hematocrit values did not differ significantly among from various ASEAN countries. Serum cholesterol more than $250 \mathrm{mg} \%$ was found in $19 \%$ of patients and hematocrit value more than 50 volume \% was found in $5 \%$ of stroke patients in ASEAN countries, except in Vietnam. 


\section{Neuroimaging investigation}

Of the 3723 stroke patients in this study, CT scan was performed on 2801 (76\%) patients and most of them showed positive results. Of the patients with an identified type of stroke, non lacunar anterior circulation was the most common type (1186 patients or $32 \%$ ) found among the patients from all partici- pating countries (see Table 6). There were 524 patients $(14 \%)$ with lacunar infarction, particularly in Singapore (34\%). Hemorrhagic strokes were found in 958 patients $(26 \%)$. Subarachnoid hemorrhage was only found in 152 patients (4\%), particularly highest in Vietnam and Thailand (up to $12 \%$ and 18\%, respectively).

Table 5. Risk Factors of Hospitalized Stroke Patients in Seven ASEAN Countries

\begin{tabular}{|c|c|c|c|c|c|c|c|c|}
\hline Risk factors & Brunei & Indonesia & Malaysia & Philippines & Singapore & Thailand & Vietnam & Total \\
\hline Prior stroke & $9(17)$ & $409(20)$ & $26(9)$ & $110(20)$ & $44(19)$ & $45(19)$ & $19(7)$ & $660(18)$ \\
\hline Prior TIA & $3(6)$ & $73(4)$ & $24(8)$ & $45(8)$ & $8(3)$ & $6(3)$ & $99(35)$ & $260(7)$ \\
\hline \multicolumn{9}{|l|}{ Hypertension } \\
\hline - untreated & $4(8)$ & $689(34)$ & $31(10)$ & $158(29)$ & $16(7)$ & $55(23)$ & $13(5)$ & $966(26)$ \\
\hline - treated & $20(38)$ & $647(32)$ & $142(47)$ & $214(39)$ & $143(62)$ & $38(16)$ & $87(31)-$ & $1291(35)$ \\
\hline - admission & $5(9)$ & $182(9)$ & $8(3)$ & $19(4)$ & - & $42(17)$ & - & $256(7)$ \\
\hline - unknown & $3(6)$ & $77(4)$ & $1(0.3)$ & $9(2)$ & $2(1)$ & $5(2)$ & - & $97(3)$ \\
\hline \multicolumn{9}{|l|}{ Diabetes Mellitus } \\
\hline - untreated & - & $106(5)$ & $4(1)$ & $20(4)$ & $4(2)$ & $9(4)$ & - & $143(4)$ \\
\hline - treated & $12(23)$ & $149(7)$ & $74(25)$ & $42(8)$ & $78(34)$ & $21(9)$ & $3(1)$ & $379(10)$ \\
\hline - admission & $1(2)$ & $100(5)$ & $6(2)$ & $6(1)$ & $3(1)$ & $19(8)$ & - & $135(4)$ \\
\hline - unknown & $3(6)$ & $117(6)$ & $1(0.3)$ & $10(2)$ & $1(0.4)$ & $9(4)$ & - & $140(4)$ \\
\hline \multicolumn{9}{|l|}{ Smoking } \\
\hline -recent & $12(23)$ & $277(14)$ & $89(30)$ & $193(35)$ & $38(16)$ & $60(25)$ & $32(11)$ & $701(19)$ \\
\hline \multicolumn{9}{|l|}{-stopped } \\
\hline$-<5 y$ & $1(2)$ & $87(4)$ & $10(3)$ & $25(5)$ & $4(2)$ & $15(6)$ & $26(9)$ & $168(5)$ \\
\hline$-5-10 y$ & - & $33(2)$ & $5(2)$ & $18(3)$ & $1(0.4)$ & $5(2)$ & $2(0.7)$ & $63(2)$ \\
\hline$->10 y$ & $1(2)$ & $23(1)$ & $9(3)$ & $8(2)$ & $1(0.4)$ & $7(3)$ & $12(4)$ & $61(2)$ \\
\hline $\begin{array}{l}\text { Contraceptive } \\
\text { pill }\end{array}$ & - & $29(1)$ & $2(0.7)$ & $11(2)$ & $2(0.9)$ & $1(0.9)$ & $1(0.4)$ & $46(1,2)$ \\
\hline Alcohol & $2(4)$ & $28(1)$ & $32(11)$ & $175(32)$ & $7(3)$ & $76(31)$ & $89(31)$ & $409(11)$ \\
\hline Atrial fibrillation & $5(9)$ & $120(6)$ & $17(6)$ & $36(7)$ & $21(9)$ & $25(10)$ & $1(0.4)$ & $225(6)$ \\
\hline $\begin{array}{l}\text { Ischemic heart } \\
\text { disease }\end{array}$ & $5(9)$ & $409(20)$ & $56(19)$ & $140(26)$ & $55(24)$ & $29(12)$ & $3(1)$ & $697(19)$ \\
\hline \multicolumn{9}{|l|}{$\begin{array}{l}\text { Valvular Heart } \\
\text { disease }\end{array}$} \\
\hline - Mitral & $1(2)$ & $51(3)$ & $8(3)$ & $16(3)$ & $6(3)$ & $23(10)$ & $1(0.4)$ & $106(3)$ \\
\hline - Aortic & $1(2)$ & $14(1)$ & $1(0.3)$ & $1(0.2)$ & $1(0.4)$ & $1(0.4)$ & $2(0.7)$ & $21(0.6)$ \\
\hline - Both & $3(2)$ & $5(0.5)$ & - & - & - & - & - & $8(0.2)$ \\
\hline $\begin{array}{l}\text { Congestive heart } \\
\text { disease }\end{array}$ & $1(2)$ & $71(4)$ & $9(3)$ & $26(5)$ & $11(5)$ & $11(5)$ & $3(1)$ & $129(4)$ \\
\hline \multicolumn{9}{|l|}{$\begin{array}{l}\text { Serum cholesterol } \\
(\mathrm{mg} \%)\end{array}$} \\
\hline -mean & 220.9 & 209.4 & 225.7 & 214.5 & 245.8 & 211.9 & no data & 221.4 \\
\hline$-s d$ & 54.6 & 55.6 & 49.2 & 37.5 & 73.6 & 58.2 & & 54.8 \\
\hline -range & $113-370$ & $50-855$ & $81-397$ & $161-363$ & $100-688$ & $62-383$ & & $50-855$ \\
\hline$->250$ & $13(25)$ & $338(16)$ & $67(22)$ & $10(14)$ & $60(26)$ & $26(11)$ & & $514(19)$ \\
\hline \multicolumn{9}{|l|}{$\begin{array}{l}\text { Hematocrit } \\
(\text { vol\%) }\end{array}$} \\
\hline -mean & 39.3 & 40.2 & 41.9 & 41.1 & 41.2 & 38.6 & 38.7 & 40.3 \\
\hline$-S D$ & 6.5 & 5.9 & 5.1 & 4.9 & 5.8 & 6.7 & 3.4 & 5.7 \\
\hline -range & $25-53$ & $10-65$ & $19-60$ & $28-52$ & $13-54$ & $13-54$ & $30-48$ & $10-65$ \\
\hline$->50$ & $1(2)$ & $75(4)$ & $14(5)$ & $9(3)$ & $11(5)$ & $10(4)$ & $0(0)$ & $131(5)$ \\
\hline
\end{tabular}


Table 6. Type of Stroke among the Hospitalized Stroke Patients, Diagnosed by CT Scan in ASEAN Countries

\begin{tabular}{|c|c|c|c|c|c|c|c|c|}
\hline \multirow[t]{2}{*}{ Total subject } & Brunei & Indonesia & Malaysia & Philippines & Singapore & Thailand & Vietnam & Total \\
\hline & $\mathrm{n}=53$ & $n=2065$ & $\mathrm{n}=300$ & $\mathrm{n}=545$ & $\mathrm{n}=232$ & $n=244$ & $\mathrm{n}=284$ & $n=3723$ \\
\hline \multicolumn{9}{|l|}{$\begin{array}{l}\text { no.of CT } \\
\text { done }\end{array}$} \\
\hline -positive & $41(77)$ & $1102(54)$ & $294(98)$ & $451(83)$ & $196(85)$ & $181(75)$ & $250(88)$ & $2515(68)$ \\
\hline -negative & $9(17)$ & $167(8)$ & $2(0.7)$ & $40(7)$ & $28(12)$ & $33(14)$ & $7(3)$ & $286(8)$ \\
\hline Lacunar & $9(17)$ & $241(12)$ & $70(23)$ & $90(17)$ & $79(34)$ & $18(7)$ & $17(6)$ & $524(14)$ \\
\hline $\begin{array}{l}\text { non lac ant } \\
\text { circulation }\end{array}$ & $24(45)$ & $555(27)$ & $131(44)$ & $223(41)$ & $67(29)$ & $68(28)$ & $118(42)$ & $1186(32)$ \\
\hline $\begin{array}{l}\text { non lac post } \\
\text { circulation }\end{array}$ & $3(6)$ & $86(4)$ & $21(7)$ & $29(5)$ & $19(8)$ & $18(7)$ & $9(3)$ & $185(5)$ \\
\hline $\mathrm{SAH}$ & $2(4)$ & $29(1)$ & $9(3)$ & $26(5)$ & $6(3)$ & $28(12)$ & $52(18)$ & $152(4)$ \\
\hline lobar & $2(4)$ & $180(9)$ & $43(14)$ & $66(12)$ & $5(2)$ & $21(9)$ & $40(14)$ & $357(10)$ \\
\hline $\begin{array}{l}\text { hemorraghe } \\
\text { ganglionic } \\
\text { hemorraghe }\end{array}$ & $8(15)$ & $146(7)$ & $23(8)$ & $64(12)$ & $24(10)$ & $59(24)$ & $26(9)$ & $350(9)$ \\
\hline $\begin{array}{l}\text { brainstem } \\
\text { hemorraghe }\end{array}$ & - & $34(2)$ & $2(0.7)$ & $9(2)$ & $4(2)$ & $4(2)$ & $3(1)$ & $63(2)$ \\
\hline $\begin{array}{l}\text { cerebellum } \\
\text { hemorraghe }\end{array}$ & $2(4)$ & $18(1)$ & $1(0.3)$ & $6(1)$ & $4(2)$ & $4(2)$ & $3(1)$ & $36(1)$ \\
\hline $\begin{array}{l}\text { unknown } \\
\text { (no CT) }\end{array}$ & $3(6)$ & $796(39)$ & $4(3)$ & $54(9)$ & $8(3)$ & $30(12)$ & $27(10)$ & $922(24)$ \\
\hline
\end{tabular}

values are number ( percentage )

Table 7. Hospital Discharge Status of Stroke Patients in ASEAN Countries

\begin{tabular}{|c|c|c|c|c|c|c|c|c|}
\hline & $\begin{array}{c}\text { Brunei } \\
n=53\end{array}$ & $\begin{array}{c}\text { Indonesia } \\
\mathrm{n}=2065\end{array}$ & $\begin{array}{c}\text { Malaysia } \\
\mathrm{n}=300\end{array}$ & $\begin{array}{c}\text { Philippines } \\
n=545\end{array}$ & $\begin{array}{c}\text { Singapore } \\
n=232\end{array}$ & $\begin{array}{c}\text { Thailand } \\
\mathrm{n}=244\end{array}$ & $\begin{array}{c}\text { Vietnam } \\
\mathrm{N}=284\end{array}$ & $\begin{array}{c}\text { Total } \\
n=3723\end{array}$ \\
\hline $\begin{array}{l}\text { alive, } \\
\text { unchanged }\end{array}$ & $l(2)$ & $182(9)$ & $31(10)$ & $71(13)$ & $41(18)$ & $19(8)$ & $10(4)$ & $355(10)$ \\
\hline alive, improved & $46(88)$ & $1171(57)$ & $136(45)$ & $373(68)$ & $117(50)$ & $102(42)$ & $176(62)$ & $2121(57)$ \\
\hline alive, worsened & - & $33(2)$ & $34(11)$ & $12(2)$ & $5(2)$ & $1(0.4)$ & $34(12)$ & $119(3)$ \\
\hline dead & $4(8)$ & $479(23)$ & $87(29)$ & $68(13)$ & $31(13)$ & $108(45)$ & $31(11)$ & $808(22)$ \\
\hline alive, status not & - & $88(4)$ & $12(4)$ & $8(1.5)$ & $36(16)$ & $10(4)$ & $14(5)$ & $168(5)$ \\
\hline unknown & $1(2)$ & $104(5)$ & $1(0.3)$ & $13(2)$ & $2(0.9)$ & $2(0.8)$ & $17(6)$ & $137(4)$ \\
\hline
\end{tabular}

values are number (percentage)

Table 8. Length of Hospital Stay of Stroke Patients in ASEAN Countries

\begin{tabular}{lllllllll}
\hline $\begin{array}{l}\text { Length of } \\
\text { hospital stay } \\
\text { (day) }\end{array}$ & $\begin{array}{l}\text { Brunei } \\
\mathrm{n}=53\end{array}$ & $\begin{array}{l}\text { Indonesia } \\
\mathrm{n}=2065\end{array}$ & $\begin{array}{l}\text { Malaysia } \\
\mathrm{n}=300\end{array}$ & $\begin{array}{l}\text { Philippines } \\
\mathrm{n}=545\end{array}$ & $\begin{array}{l}\text { Singapore } \\
\mathrm{n}=232\end{array}$ & $\begin{array}{l}\text { Thailand } \\
\mathrm{n}=244\end{array}$ & $\begin{array}{l}\text { Vietnam } \\
\mathrm{n}=284\end{array}$ & $\begin{array}{l}\text { Total } \\
\mathrm{n}=3723\end{array}$ \\
\hline Mean & 19.1 & 10.9 & 8.9 & 8.2 & 16.6 & 17.5 & 13.1 & 11.4 \\
SD & 18.6 & 9.6 & 7.3 & 9.6 & 20.8 & 19.0 & 9.2 & 11.8 \\
Range & & & & & & & & $1-99$ \\
\hline
\end{tabular}

Values are mean days ( standard of deviation ) 


\section{Outcome}

Of 3723 patients admitted to the hospitals in seven ASEAN countries, 2121 patients $(57 \%)$ were aliveimproved after hospital discharge and worsening strokes were found only in 168 (3\%) of patients. Inhospital case fatality rates of all countries were $22 \%$. Thailand had a higher case fatality rate $(45 \%)$ than the other countries (8-29\%) (Table 7).

\section{Length of hospital stay}

The length of hospital stay of 3723 stroke patients was $11.4 \pm 11.8$ days (range, 1 to 99 days). Mean of length of stay also varied by type of stroke and discharge status. Patients with ischemic stroke were hospitalized on average 9.4 days for lacunar infarction, 11.8 days for non lacunar anterior circulation and 13.9 days for posterior circulation, and 15 days for hemorrhagic stroke. Among the surviving stroke patients, the mean of length of stay was ranging from 9.1 to 17.6 days. The length of stay of the fatal stroke patients was 6.2 days, it was longest in Singapore (16.4 days) .Most of the patients (85.9 $\%)$ were hospitalized for 1-3 weeks.

\section{DISCUSSION}

Several important informations emerged from stroke patients hospitalized in ASEAN region which as occupied by one fifth of world population. It has always been questioned whether there would were be a specific clinical picture or risk factor of stroke in this region caused by the differences of culture, food habit, environtmental condition and may be genetic constituents. $^{1,2}$

The demographic characteristics in this study showed that, there were no differences exist compared those reported in the western population. ${ }^{3,4}$ Some clinical factors were also studied prospectively. These informations were important because of the impact on the stroke services in the community, either on prevention or on treatment after discharge from the hospital. The duration from the onset to the hospital admission is important because this reflects, in part, the awareness of the community on the important of early treatment of stroke. This study showed that one third of patients admitted to hospital in early stage (less than 6 hour). The most frequent of early admission was found among the stroke patients in Thailand (48\%). Delayed admissions were seen in
$66 \%$ and $19 \%$ more than 24 hours. The longest admission in this study was 968 hours (found in a patients in Indonesia). The reason of delayed admission were, because prior the hospital adminission they looked for the traditional medicine or treated by traditional doctor. ${ }^{4,5,6,7,8,9}$

Nowadays, the treatment for thrombolysis with r-tPA is preferred if the hospital admission less than 3 hours after onset. In this study, stroke patients with admission time less than 3 hours were only 10\% (in Malaysia) to $37 \%$ (in Thailand). Great effort should be done through public education by the medical community, to rise the prevalence of patients with hospital admission less than 3 hours. In addition, early admission of the patients to stroke units for neurorestorative has proved will improve the outcome of stroke patients, regardless of pharmacological treatment given.

The clinical features of our stroke patients showed that most of them were suffered from motor disability $(89 \%)$ and sensory symptoms (30\%). Disabilities that would be expected to be the problems in rehabilitation were hemianopia $(6,6 \%)$ and dysphasia $(20 \%)$. These clinical features, hemisensory symptoms, dysphasia and hemianopia are major symptoms associated with difficult rehabilitation, since better rehabilitation services for stroke victim is mandatory. $9,10,11,12,13,14$

It is interesting that in this study only $1.4 \%$ of our patients had carotid bruit which is easily detected by simple stethoscope. Confirmation of the degree of carotid stenosis should be confirmed by Transcranial Doppler studies or four vessels angiogram were only performed in a few hospital in ASEAN countries, especially in provincial hospital in Malaysia, Indonesia, Philippines, Thailand, and Vietnam. ${ }^{20}$

Risk factors for stroke in ASEAN Countries are not different from those in the developed countries (Table 5). Hypertension was found in $67.5 \%$, prior stroke/ TIA in $26.1 \%$, diabetes mellitus in $17.6 \%$, smoking in $18.8 \%$. Small proportion of the patients had risk factor for cerebral emboli from valvular heart disease $(3.6 \%)$ and coronary heart disease $(3.5 \%)$. Cholesterol level was found abnormal in $19 \%$ of cases. It is interesting that, although our primary food consumption were high carbohydrate (rice), the number of stroke patients with diabetes mellitus were low (less than $20 \%$ ). $15,16,17,18,19$ 
In regard to stroke diagnosis, differentiation were based on CT scan findings. We divided lacunar stroke into anterior and posterior circulation based on CT scan and clinical findings (Table 6). Lacunar infarctions were found in $14 \%$ of cases, non lacunar anterior circulation stroke in $32 \%$, and posterior circulation stroke in only $5 \%$. A total of $22 \%$ of cases were hemorrhagic stroke, consisted of 9.6 lobar hemorrhage, and $3.4 \%$ ganglionic hemorrhage. Brainstem and cerebellum hemorrhage were seen in $1.7 \%$ and $1 \%$, respectively. SAH were diagnosed in $4.1 \%$ of cases. These data did not differ from other countries. $21,22,23,24,25,26,27,28$

In this study the hospital discharge status and length of stay of the patients (Table 7). In Asean countries we found that $57 \%$ of the stroke patients were alive and improved, $9.5 \%$ alive-unchanged and $3.2 \%$ alive worsened. Mortality among the stroke patients were $22 \%$. Mortality in cerebral hemorrhage was $38.3 \%$ while in ischemic stroke was $28.9 \%$. $29,30,31,32,33,34,35,36,37$ The. prevalence of alive improved patients among those with cerebral hemorrhage $(20.9 \%)$ was lower than those with ischemic stroke.

In conclusion, this hospital based stroke data showed the recent characteristics of stroke pattern in seven ASEAN member countries and it will be very important data for health policy maker in these countries and for further cooperative researches in the future.

\section{Acknowledgement}

This study was conducted by the cooperation of neurologists from Brunei, Malaysia, Indonesia, Philippines, Singapore, Thailand and Vietnam, who participated in the ASNA Stroke Epidemiological Study I by their representatives as follows,

Dr. Jusuf Misbach ( Chairman, Indonesia),Dr. On Sui Chee (Brunei), Dr. Ng Wai Keong and Dr. Hanif Raphia (Malaysia), Dr.Ester Bitanga (Philipinnes), Dr.Lee Sze Haur (Singapore), Prof Niphon Poungvarin (Thailand), Prof. Le Duc Hinh (Vietnam). The author acknowledges the sincere thanks to Dr. Djaja Surya Atmadja PhD, Dr. Wendra Ali and Dr.Andradi Suryamihardja for editing and revising the manuscript.

\section{REFERENCES}

1. WHO MONICA Project, Principal Investigators. The World Health Organization MONICA Project (monitoring trends and determinants in cardiovascular disease): a major international collaboration. J Clin Epidemiol 1988; 41: 105-14.

2. Bamford J, Sandercock P, Dennis M, Burn J, Warlow C. Classification and natural history of clinically identifiable subtypes of cerebral infarction. Lancet 1991 ; 337 : 1521-6.

3. Turney TM, Garraway WM, Whisnant JP. The natural history of hemispheric and brainstem infarction in Rochester, Minnesota. Stroke 1984; 15: 790-4.

4. Gogelholm R, Murros K, Rissanen A, Ilmavirta M. Factors delaying hospital admission after acute stroke. Stroke 1996;27:398-400.

5. Anderson NE, Broad JB, Bonita R. Delays in hospital admission and investigation in acute stroke. BMJ 1995;311:162

6. Feldmann E, Gordon N, Brooks JM, Fayd PB, Sawaya KL, Nazareno F, et al. Factors associated with early presentation of acute stroke. Stroke 1993;24: 1805-10

7. Harper GD, Haigh RA, Potter JF, Castleden CM. Factors delaying hospital admission after stroke in Leicestershire. Stroke 1992;23:835-8.

8. Biller J, Shepard A, Adams HP. Delay time between onset of ischemic stroke and hospital arrival. Neurology 1992;42 (suppl 3):250. Abstract.

9. Bogousslavsky J, Melle GV, Regli F. The Lausanne Stroke Registry: analysis of 1000 consecutive patients with first stroke.Stroke 1988;19:1083-92.

10. Caplan LR, Kargman DE, Gu Q, Zamanillo MC. Race, sex and occlusive cerebrovascular disease: a review. Stroke 1986;17:648-55.

11. Chambers BR, Donnan GA, Baldin PF. Pattern of stroke: an analysis of the first 700 consecutive admission to the Austin Hospital stroke unit. Aust N Z J Med 1983;13:5764.

12. Rothrock JF, Lyden PD, Brody ML, Taft-Alvarez B, Kelly $\mathrm{N}$, Mayer $\mathbf{J}$, et al. An analysis of ischemic stroke in an urban southern califomia population: the University of california, san Diego, Stroke Data Bank. Arch Intern Med 1993;153:619-24.

13. Sacco Rl, Shi T, Zamanillo MC, Kargman DE. Predictors of mortality and recurrence after hospitalized cerebral infarction in an urban community: the Northern Manhattan Stroke Study. Neurology 1994;44:626-34.

14. Gillum RF. The epidemiology of stroke in Native Americans. Stroke 1995;26:2222-7.

15. Burchfiel CM, Curb JD, Rodriquez BL, Abbott RD, Chiu D, Yano K. Glucose intolerance and 22- year stroke incidence: the Honolulu Heart Program. Stroke 1994;25:951-7.

16. Risk factors for stroke and efficacy of antithrombotic therapy in atrial fibrillation: analysis of pooled data from five randomized controlled trials. Arch Intern Med 1994;154:1449-57. 
17. Shinton R, Beevers G. Meta-analysis of relation between cigarette smoking and stroke.BMJ 1989;298:789-94.

18. Wolf PA, D'Agostino RB, Kannel WB, Bonita R, Belanger AJ. Cigarette smoking as a risk factor for stroke: the Framingham Study.JAMA 1993;269:232-6.

19. Camargo CA Jr. Moderate alcohol consumption and stroke: the epidemiologic evidence. Stroke 1989;20:1611-6.

20. Wolf PA, Kannel WB,Sorlie P, Mc Namara P. Asymptomatic neck bruits. N Eng J Med 1986;315: 860-5.

21. Howard G, Evans GW, Crouse JR III, Toole JF, Ryu JE, Tegeler $\mathrm{C}$, et al. A prospective reevaluation of transient ischemic attacks as a risk factor for death and fatal or nonfatal cardiovascular events. Stroke $1994 ; 25$ :342-5.

22. Sacco RL, Wolf PA, Kannel WB, Mc Namara PM. Survival and recurrence following stroke: the Framingham study. Stroke 1982;13:290-5.

23. Petitti DB, Sidney S, Bernstein A, Wolf S, Quesenberry C, Ziel HK. Stroke in users of low-dose oral contraceptives. N Eng J Med 1996;335:8-15.

24. Iso H, Jacobs DR Jr, Wentworth D, Neaton JD, Cohen JD. Serum cholesterol levels and six-year mortality from stroke in 350977 men sreened for the multiple risk factor intervention trial. N Eng J Med 1989;320:904-10.

25. Summary of the National Cholesterol Education Program (NCEP) Adult Treatment Panel II report. JAMA 1993;269:3015-23.

26. Wolf PA, Benyamin EJ, Belanger AJ, Kannel WB, Levy D, D'Agostino RB. Secular trends in the prevalence of atrial fibrillation: the Framingham Study. Am Heart , J 1996;131:790-5.

27. Wolf PA, Abbott RD, Kannel WB. Atrial fibrillation as an independent risk factor for stroke: the Framingham Study, Stroke 1991;22:983-8.

28. Rutan GH, Kuller LH, James PH. Mortality associated with diastolic hypertension and isolated systolic hypertension among men sreened for the Multiple Risk Factor Intervention Trial. Hypertension 1988;77:504-14.

29. Broderick JP. Intracerebral hemorrhage. In: Gorelick PB, Alter M, eds. Handbook of Neuroepidemiology. New York, NY: Marcel Dekker Inc 1994: 223-5

30. Mac Mahon S, Rodgers A. The epidemiological association between blood pressure and stroke: implications for primary and secondary prevention. Hypertension 1994;17(suppl 1): S23-32.

31. Whisnant JP. Effectiveness versus efficacy of treatment of hypertension for stroke prevention. Neurology 1996;46: 301-7.

32. Dyken ML, Wolf PA, Barnett HJM, Bergan JJ, Ha WK, Kannel WB, et al. Risk factors in stroke. Stroke 1984;15:1105-11.

33. Sandercock P, Molyneaux A, Warlow C. Value of computerised tomography in patients with stroke: the Oxfordshire Community Stroke Project. Br Med J 1985; 290: 193-7.

34. Bamford J, Dennis M, Sandercock Pl. The frequency, causes and timing of death within 30 days of a first stroke: the Oxfordshire Stroke Project. J Neurol Neurosurg Psychiatry 1990;53: 824-9.

35. Rajeh SA, Awada A, Niazi G. Stroke in a Saudi Arabian National Guard Community: Analysis of 500 Consecutive Cases From a Population-Based Hospital. Stroke 1993;24:1635-9.

36. Ellekjaer H, Holmen J, Indredavik B. Epidemiology of Stroke in Innherred, Norway, 1994 to 1996: Incidence and 30-Day Case Fatality Rate. Stroke 1997;28:2180-4.

37. Mayo NE, Wood-Dauphinee S, Gayton D. Nonmedical Bed-Days for Stroke Patients Admitted to Acute-Care Hospitals in Montreal, Canada. Stroke 1997;28:543-9. 